\title{
Salinity Tolerance of Flathead Catfish: Implications for Dispersal of Introduced Populations
}

\author{
ROBERT B. BRINGOLF* \\ Department of Environmental and Molecular Toxicology, Campus Box 7633, \\ North Carolina State University, Raleigh, North Carolina 27695-7633, USA
}

THOMAS J. KWAK

U.S. Geological Survey, North Carolina Cooperative Fish and Wildlife Research Unit, ${ }^{1}$ Department of Zoology, Campus Box 7617, North Carolina State University, Raleigh, North Carolina 27695-7617, USA

\section{W. Gregory Cope}

Department of Environmental and Molecular Toxicology, Campus Box 7633, North Carolina State University, Raleigh, North Carolina 27695-7633, USA

\section{MichAEL S. LARIMORE}

Peter W. Pfeiffer Fish Hatchery, Kentucky Department of Fish and Wildlife Resources, 1883 Indian Gap Road, Frankfort, Kentucky 40601, USA

\begin{abstract}
The flathead catfish Pylodictis olivaris is a large predatory fish that has been introduced widely beyond its indigenous range to the detriment of many native fish communities. It disperses rapidly within and among river systems, but its potential to use saltwater or brackish waters for migration and exploitation of marine prey resources is unknown. We evaluated the salinity tolerance of juvenile flathead catfish exposed to $\mathrm{NaCl}$ and synthetic seawater (0-34\%o) in direct-transfer acute toxicity tests. The 96-h median lethal concentration (LC50) for fish exposed to $\mathrm{NaCl}$ at $18^{\circ} \mathrm{C}$ was a salinity of $10.0 \%$ with a $95 \%$ confidence interval (CI) of $9.0-11.1 \%$, whereas the $96-\mathrm{h}$ LC50 for fish in synthetic seawater (Instant Ocean) at $18^{\circ} \mathrm{C}$ was $14.5 \%$ (95\% CI, 13.7-15.5\%o). To determine whether fish could survive the transition from freshwater to brackish water and then back to freshwater, fish were transferred from freshwater at $18^{\circ} \mathrm{C}$ to water with a salinity of 8,11 , or $14 \%$ ofor $24 \mathrm{~h}$ and then returned to freshwater for $48 \mathrm{~h}$. Fish exposed to synthetic seawater with a salinity of 8 or $11 \%$ for $24 \mathrm{~h}$ had more than $95 \%$ survival for $48 \mathrm{~h}$ after transfer to freshwater; however, no fish transferred directly to synthetic seawater with a salinity of $14 \%$ survived the $24-$ $\mathrm{h}$ exposure period. Additional acclimation tests with fish that were exposed to synthetic seawater in which salinity was increased daily by $4 \%$ yielded an LC50 of $15.8 \%$. Our results provide evidence that flathead catfish could tolerate exposure to many brackish waters along the Atlantic and Gulf of Mexico coasts of the United States and that the dispersal of introduced flathead catfish populations among rivers may not be limited by estuarine salinities.
\end{abstract}

The flathead catfish Pylodictis olivaris is a large predatory catfish that has been introduced widely beyond its native range, including into coastal rivers of the Gulf of Mexico and the Atlantic slope of the United States. Native to the Mississippi, Mobile, and Rio Grande drainages and to portions of the Great Lakes region and northern Mexico,

\footnotetext{
* Corresponding author: robert_bringolf@ncsu.edu

1 The Unit is jointly supported by North Carolina State University, North Carolina Wildlife Resources Commission, U.S. Geological Survey, and Wildlife Management Institute.
}

Received October 27, 2004; accepted March 18, 2005 Published online June 22, 2005 this fish has been introduced into waters of at least 13 states and one Canadian province (Jackson 1999). Populations are easily established, by translocation of as few as 11 individuals, and this species can become the dominant predator in a river as rapidly as 15 years after introduction (Guier et al. 1984; Jenkins and Burkhead 1994). Introduced flathead catfish populations exist today in a majority of coastal river systems on the Atlantic slope of the United States from Georgia to Pennsylvania as well as in those of the Florida panhandle.

The rapid dispersal within and among rivers, high individual and population growth rates, and obligate carnivorous food habits of the flathead catfish have raised concern for native fish conser- 
vation in river drainages where the flathead catfish is introduced. Introduced flathead catfish have been implicated in reducing populations of native bullheads (Ameiurus spp.) and the redbreast sunfish Lepomis auritus, an important sport fish (Guier et al. 1984; Thomas 1995; Ashley and Rachels 2000). Diet studies have also documented predation of juvenile and adult anadromous shad (Alosa spp.) by introduced flathead catfish, which may impede restoration efforts for these fishes in Atlantic coastal rivers (Ashley and Buff 1988; Kwak et al. 2004); other imperiled fishes also are thought to be threatened by introduced flathead catfish (Fuller et al. 1999). Simulation modeling of the food web further supports and elucidates the hypothesis that direct predation by introduced flathead catfish suppresses native freshwater resident and anadromous fish populations in coastal rivers (Pine 2003).

State fishery management agencies have introduced the flathead catfish intentionally in a number of reservoirs and river systems, but the predominant mode of population introduction and establishment among rivers has been assumed to be translocation by well-meaning anglers to establish recreational fisheries; however, that speculation remains unconfirmed for most populations. Another potential dispersal mechanism among coastal rivers could be natural fish migration along the coastline. Under typical hydrologic conditions, one might assume that seawater salinity would preclude migration of this freshwater fish among coastal rivers, but coastal waters connecting river mouths are often brackish, and the salinity tolerance of flathead catfish is unknown. Thus, the extent of the physiological limit of the downstream distribution and migratory capability of this fish also remain unknown.

The maximum salinity tolerance of a fish may not be accurately defined solely by field observations of the maximum salinity in which fish have been captured (Kefford et al. 2004). For example, fish distribution may be influenced by other factors that co-occur with the higher salinities, such as temperature, $\mathrm{pH}$, oxygen concentration, and food and habitat availability. Sampling efforts for freshwater fish may not be comprehensive in highsalinity waters, where common freshwater sampling techniques may be less effective or impractical (e.g., electrofishing). Furthermore, geographic distribution of fish species may be limited to low-salinity waters.

Unlike field observations, experimental determinations of salinity tolerance establish a causal link between salinity and mortality. The most common experimental measure of salinity tolerance is the acute LC50 (median lethal concentration). Because of their highly controlled and simplified nature, standard acute toxicity tests with metals and organic compounds are rarely used for predictive purposes but are commonly used comparatively. However, laboratory-derived acute salinity tolerance values have been reported to reflect the maximum salinity that macroinvertebrates and fish species inhabit in the environment (Kefford et al. 2004), and acute salinity tolerance has been used to describe spatial zonation and assemblage patterns of prairie stream fishes (Ostrand and Wilde 2001). Additionally, results of acute salinity tolerance tests have been used to predict the likelihood for range expansion of nonindigenous species in estuarine environments (Matern 2001).

Here we report the results of a series of laboratory tests designed to evaluate the potential for flathead catfish to use coastal waters as dispersal routes between or among river systems. To our knowledge, this is the first report of salinity tolerance of flathead catfish. We tested (1) the acute toxicity of sodium chloride and synthetic seawater to juvenile flathead catfish, (2) the potential for flathead catfish to acclimate to brackish water, and (3) the survival of flathead catfish that were cultured in freshwater, exposed to brackish water for a short period, and returned to freshwater.

\section{Methods}

Test fish.-Juvenile flathead catfish were obtained from the Peter W. Pfeiffer State Fish Hatchery in Frankfort, Kentucky. The fish were originally hatched from a feral egg mass collected on 12 July 2004 from the Ohio River near Warsaw, Kentucky. The propagation of flathead catfish in intensive aquaculture settings has previously met with limited and varied success. The successful culture conditions that led to propagation of fish used in this study included a water temperature of $25.5^{\circ} \mathrm{C}$, a photoperiod of $24: 0$ light : dark, rearing densities of approximately 20 fry/L, and a feeding rate of more than $20 \%$ body weight per day divided over 3-4 high-protein feedings/d (Purina Trout Chow). The 25-d-old fish were double-bagged in hatchery water $(\mathrm{pH} 7.8$, alkalinity $120 \mathrm{mg} / \mathrm{L}$ as $\mathrm{CaCO}_{3}$, hardness $180 \mathrm{mg} / \mathrm{L}$ as $\mathrm{CaCO}_{3}$ ) and shipped by next-day air in chilled Styrofoam coolers to the Aquatic Toxicology Laboratory in the Department of Environmental and Molecular Toxicology, North Carolina State University in Raleigh, North Carolina. Upon arrival, flathead catfish were ac- 
climated to reconstituted hard water (ASTM 1993) for $6 \mathrm{~h}$ at $18 \pm 1^{\circ} \mathrm{C}$ and $9.1 \pm 0.7 \mathrm{mg} / \mathrm{L}$ dissolved oxygen in a 250 -L fiberglass tank before experimentation began. Mean total length and wet weight of the test fish (determined on a random subsample of $42 \mathrm{fish}$ ) were $41 \mathrm{~mm}$ (range 37-44) and $0.71 \mathrm{~g}$ (range 0.44-0.94). Fish were not fed during the experiments, and the photoperiod was maintained at $24 \mathrm{~h}$ light : $0 \mathrm{~h}$ dark (consistent with hatchery conditions) during testing to minimize potential aggressive and cannibalistic behavior. We observed no evidence of cannibalism during any of the tests.

Salinity tolerance tests.-The salinity tolerance of juvenile flathead catfish was determined in concurrent static toxicity tests with $\mathrm{NaCl}$ and a synthetic seawater solution. Desired salinities were achieved by dissolving either ACS-grade $\mathrm{NaCl}$ (Sigma-Aldrich, St. Louis, Missouri) or Instant Ocean (Aquarium Systems, Mentor, Ohio) in reconstituted hard water to the desired concentrations in test containers (experimental units), 3.78L glass aquaria containing $2 \mathrm{~L}$ of gently aerated test solution. Six fish were randomly selected and placed in each of three replicate containers for each treatment $(0.0,1.0,2.0,4.0,8.5,12.5,17.0$, and $34.0 \%$ ). Target treatment concentrations (salinities) were the same for $\mathrm{NaCl}$ and synthetic seawater tests. Survival was recorded at 12, 24, 48, 72 , and $96 \mathrm{~h}$, and any dead fish were removed from containers. Temperature and dissolved oxygen were measured daily in one replicate of each treatment chosen at random. Salinity, conductivity, $\mathrm{pH}$, alkalinity, and hardness were measured at the beginning and end of the exposures in one replicate of each treatment chosen at random.

Acclimation test.-To determine whether juvenile flathead catfish could acclimate to a higher salinity gradually, in contrast to a direct transfer from freshwater to brackish, we examined the survival of flathead catfish in water in which the salinity was incrementally increased. Each treatment consisted of two replicates of 10 fish in each of two 3.78-L glass aquaria with $2 \mathrm{~L}$ of test solution and gentle aeration. All juvenile flathead catfish were initially placed in synthetic seawater solution with a salinity of $2.0 \%$. In the first treatment group, salinity was increased at a rate of $4 \%$ o/d to a maximum concentration of $18 \%$. In the second treatment group, the salinity was increased at a rate of $8 \%$ /d to a maximum concentration of $18 \%$. Desired salinities were achieved by adding synthetic sea salts (Instant Ocean) to reconstituted hard water. Salinity, temperature, and dissolved oxygen were measured daily; pH, alkalinity, and hardness were measured at the beginning and end of the experiment. Survival was measured daily and any dead fish were removed.

Recovery test.-The survival of juvenile flathead catfish after exposure to synthetic seawater was determined in a static test. Flathead catfish were exposed to salinities of 8,11 , or $14 \%$ o for 24 $\mathrm{h}$ and then were transferred to freshwater for 48 h. Desired salinities were achieved by dissolving synthetic sea salts (Instant Ocean) in reconstituted hard water. Treatments consisted of two replicates, each with 10 fish in a 3.78-L glass aquarium with $2 \mathrm{~L}$ of test solution and gentle aeration. Survival, temperature, and dissolved oxygen were measured daily. Salinity was measured at the beginning of the experiment and when fish were transferred to freshwater. Alkalinity, hardness, conductivity, and $\mathrm{pH}$ were measured at the beginning of the experiment.

Water chemistry.-Standard methods were followed for all analyses of water quality (APHA et al. 1995). Calibrated meters were used for analysis of pH (Beckman model $\Phi$ 240; Beckman Instruments, Fullerton, California), dissolved oxygen (YSI model 58; Yellow Springs Instruments, Yellow Springs, Ohio), and salinity, conductivity, and temperature (YSI model 30). Alkalinity was determined by titration with $0.02 \mathrm{~N} \mathrm{H}_{2} \mathrm{SO}_{4}$ to $\mathrm{pH} 4.5$; hardness was determined by titration with $0.01 \mathrm{M}$ ethylenediaminetetraacetic acid (EDTA). Water chemistry parameters for all experiments were within the recommended ranges for toxicity tests conducted with fish (Table 1; ASTM 1993).

Data analysis. - TOXSTAT statistical analysis software (WEST and Gulley 1994) was used to calculate the median lethal concentration (LC50) values and $95 \%$ confidence intervals (CI) by the Spearman-Karber method, a nonparametric statistical procedure (Finney 1978). For the salinity tolerance tests, LC50 values were calculated by pooling survival data from replicates within treatments and were considered significantly different when the corresponding 95\% CIs did not overlap. In the acclimation and recovery tests, mean survival was calculated for each treatment.

\section{Results}

\section{Salinity Tolerance Tests}

Flathead catfish were more sensitive to equivalent salinities of $\mathrm{NaCl}$ than to the salinity of synthetic seawater by the end of the 96-h salinity tolerance experiments; however, the LC50 values for 
TABLE 1.-Water quality conditions during salinity tests with juvenile flathead catfish. Values are means \pm SDs with the exception of hardness and conductivity, for which the range of values is shown. The number of samples analyzed is given in parentheses.

\begin{tabular}{|c|c|c|c|c|c|c|}
\hline Test & $\begin{array}{l}\text { Temperature } \\
\left({ }^{\circ} \mathrm{C}\right)\end{array}$ & $\begin{array}{l}\text { Dissolved oxygen } \\
\text { (mg/L) }\end{array}$ & $\mathrm{pH}$ & $\begin{array}{c}\text { Alkalinity } \\
\left(\mathrm{mg} \mathrm{CaCO}_{3} / \mathrm{L}\right)\end{array}$ & $\begin{array}{c}\text { Hardness } \\
\left(\mathrm{mg} \mathrm{CaCO}_{3} / \mathrm{L}\right)\end{array}$ & $\begin{array}{l}\text { Conductivity } \\
\qquad(\mu S)\end{array}$ \\
\hline $\begin{array}{l}\mathrm{NaCl} \text { toler- } \\
\text { ance }\end{array}$ & $18.6 \pm 0.6(48)$ & $9.03 \pm 0.14$ & $8.39 \pm 0.07(11)$ & $129.4 \pm 3.5$ & 184-188 (10) & $642-52,550(28)$ \\
\hline $\begin{array}{l}\text { Synthetic } \\
\text { seawater } \\
\text { tolerance }\end{array}$ & $18.6 \pm 0.5(56)$ & $9.00 \pm 0.15(40)$ & $8.44 \pm 0.04(14)$ & $189.5 \pm 88.5$ & $186-6,180(6)$ & $642-51,250(36)$ \\
\hline Acclimation & $8.5 \pm 0$ & $8.99 \pm(1-2$ & $1 \pm$ & $160.0 \pm$ & & 4,128 \\
\hline Recovery & 0.4 & $8.92 \pm 0.09(10)$ & $8.42 \pm 0.03(5)$ & $158.7 \pm 43.7$ & $182-3,280$ & $640-20,100(5)$ \\
\hline
\end{tabular}

the two sources of salinity were not significantly different at 12 and $24 \mathrm{~h}$ (Figure 1; Table 2). The 96-h LC50 for $\mathrm{NaCl}$ at $18^{\circ} \mathrm{C}$ was a salinity of $10.0 \%$ (95\% CI, 9.0-11.1\%o), whereas the 96-h LC50 for fish in synthetic seawater at $18^{\circ} \mathrm{C}$ was a salinity of $14.5 \%$ (95\% CI, 13.7-15.5\% ; Table 2). In the synthetic seawater tolerance experiment, fish exposed to salinities of 17 and 34\%o experienced rapid mortality within the first $12 \mathrm{~h}$ of exposure; very little mortality occurred in any of the other treatments during the remainder of the experiment, which resulted in a constant LC50 between 12 and $96 \mathrm{~h}$ (Figure 1). Similarly, there was rapid mortality in the 17 and 34\% salinity treatments in the $\mathrm{NaCl}$ experiment, but flathead catfish exposed to $12.5 \%$ o NaCl died throughout the duration of the experiment, which resulted in a timedependent decrease in the $\mathrm{NaCl}$ LC50 over the duration of the experiment (Figure 1).

Survivorship curves indicate that a well-defined tolerance threshold concentration existed for both $\mathrm{NaCl}$ and synthetic seawater (Figure 2). In the syn-

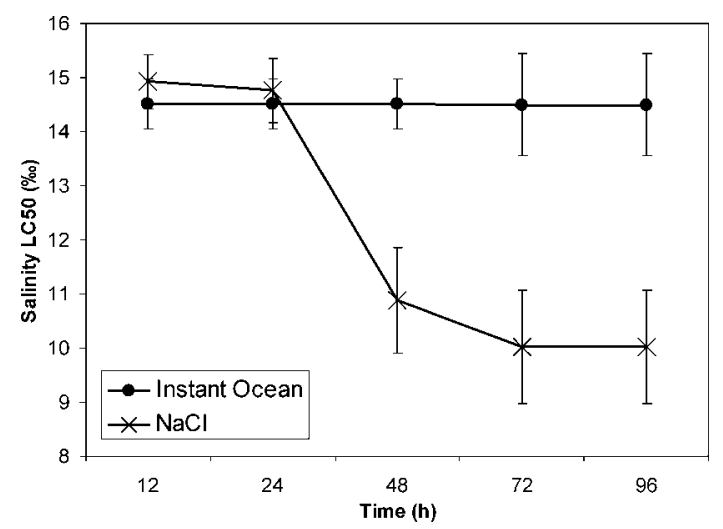

FIGURE 1.-Acute toxicity (median lethal concentration [LC50]) of $\mathrm{NaCl}$ and synthetic seawater (Instant Ocean) to juvenile flathead catfish. Error bars indicate $95 \%$ confidence intervals of the LC50 values. thetic seawater experiment, $95 \%$ of fish exposed to salinity of $12.5 \%$ o survived to $96 \mathrm{~h}$, but $0 \%$ survived $17 \%$ salinity, the next highest salinity tested. In the $\mathrm{NaCl}$ experiment, $0 \%$ of flathead catfish exposed to salinity of $12.5 \%$ o survived the 96-h exposure, but $95 \%$ of those exposed to $7.5 \%$ o salinity, the next lower salinity tested, survived for $96 \mathrm{~h}$ (Figure 2). Survival of fish in control treatments was at least $95 \%$ in all replicates for both tests.

\section{Acclimation Test}

The acute salinity tolerance (LC50) of flathead catfish was $15.8 \%$ when fish were acclimated to salinity at a rate of $4 \% / \mathrm{d}$. Survival was $95 \%$ (SD $=7.1$ ) at a salinity of $14 \%$ at $18^{\circ} \mathrm{C}$; however survival was $0 \%$ at $18 \%$, the next highest salinity tested (Figure 3). At an acclimation rate of $8 \%$ dd, survival was $100 \%$ at $10 \%$ and $0 \%$ at $18 \%$, the next highest salinity tested (Figure 3 ).

\section{Recovery Test}

Flathead catfish exposed to salinities of $8 \%$ and $11 \%$ at $18^{\circ} \mathrm{C}$ for $24 \mathrm{~h}$ and then transferred to freshwater for $48 \mathrm{~h}$ displayed mean survival of at least $95 \%$ at the end of the 72-h experiment in both treatments (Figure 4). Survival of fish exposed to salinities of $8 \%$ and $11 \%$ was consistent at 48 and $72 \mathrm{~h}$, after transfer to freshwater (Figure 4). Fish exposed to a salinity of $14 \%$ all died within the 24-h exposure period (Figure 4 ), in contrast to survival $(95 \%)$ of fish that were acclimated to a salinity of $14 \%$ (at $4 \% o / d$ ) in the acclimation test (Figure 3).

\section{Discussion}

Our results show that flathead catfish can withstand short-term exposure to mesohaline waters $(\leq 15 \%)$. The salinity tolerance of flathead catfish is remarkably similar to other members of the catfish family Ictaluridae (Table 3). Other studies in- 
TABLE 2.-Acute toxicity (median lethal concentration [LC50]; \%o) of NaCl and synthetic seawater (Instant Ocean) to juvenile flathead catfish at various times. The $95 \%$ confidence intervals are given in parentheses.

\begin{tabular}{|c|c|c|c|c|c|}
\hline Toxicant & $12 \mathrm{~h}$ & $24 \mathrm{~h}$ & $48 \mathrm{~h}$ & $72 \mathrm{~h}$ & $96 \mathrm{~h}$ \\
\hline $\mathrm{NaCl}$ & $14.9(14.4,15.4)$ & $14.8(14.2,15.4)$ & $10.9(9.9,11.9)$ & $10.0(9.0,11.1)$ & $10.0(9.0,11.1)$ \\
\hline Synthetic seawater & $14.5(14.1,15.0)$ & $14.5(14.1,15.0)$ & $14.5(14.1,15.0)$ & $14.5(13.7,15.5)$ & $14.5(13.7,15.5)$ \\
\hline
\end{tabular}

dicate that laboratory-derived salinity tolerances of catfishes are similar to field tolerance data, which allows conjecture on distribution limits in coastal waters. Channel catfish and blue catfish $I$. furcatus have been captured in salinities as high as $11.4 \%$ (Perry 1968). Channel catfish, blue catfish, and white catfish have been successfully cultured in salinities up to $11.0 \%$ (Perry and Avault 1969). Blue catfish acclimated to 5\%o salinity were able to survive for $37 \mathrm{~d}$ when exposed to $14 \%$ in laboratory tests, but only $8.3 \%$ of channel catfish in the same experiment survived for $37 \mathrm{~d}$ (Allen and Avault 1971). Stickney and Simco (1971) reported that nearly $100 \%$ of fingerling hybrid channel catfish $\times$ blue catfish survived for $96 \mathrm{~h}$ at slightly sublethal salinities (14.1-15.0\%o). Despite differences in procedures used to generate these data, the results are reasonably consistent, suggesting salinity tolerances of $10-16 \%$ o for ictalurid catfishes.

Catfish species can withstand higher salinities than most freshwater fishes, including the brook stickleback Culaea inconstans, a member of the Gasterosteidae family, which is largely a family of brackish water species (Armitage and Olund 1962). Kendall and Schwartz (1968) suggested that catfish are able to tolerate greater osmotic stress because their integument is less permeable than the scaled surfaces of most freshwater teleosts.

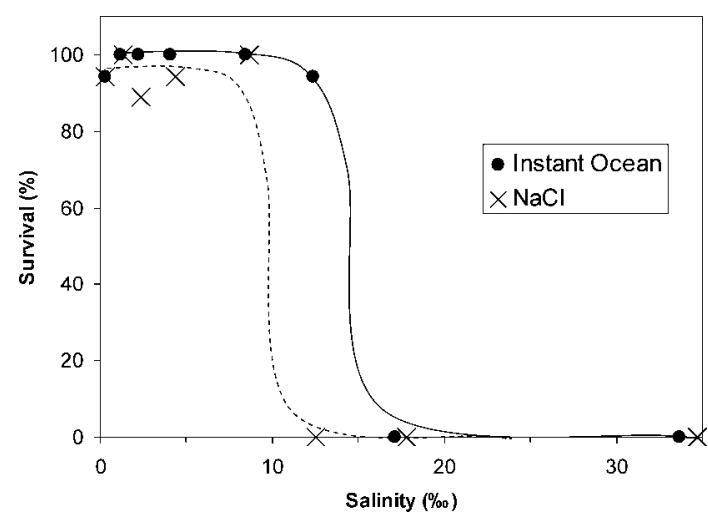

FIGURE 2.- Total survival of juvenile flathead catfish $(n=18)$ exposed to $\mathrm{NaCl}$ and synthetic seawater (Instant Ocean) for $96 \mathrm{~h}$ at salinities ranging from $0 \%$ to $34 \%$.
However, no ictalurid catfish has been known to spawn in water with salinity greater than $2.0 \%$ (Perry 1973), which may serve to restrict their coastal distribution.

Salinity tolerance tests with fish have been performed with $\mathrm{NaCl}$ (Arunachalam and Reddy 1979; Matern 2001; Ostrand and Wilde 2001), diluted seawater (Allen and Avault 1971; Kendall and Schwartz 1968; Chen and Chen 2000), and synthetic seawater (Stickney and Simco 1971; Myers and Kohler 2000; Partridge and Jenkins 2002; Haney and Walsh 2003; Kefford et al. 2004). Based
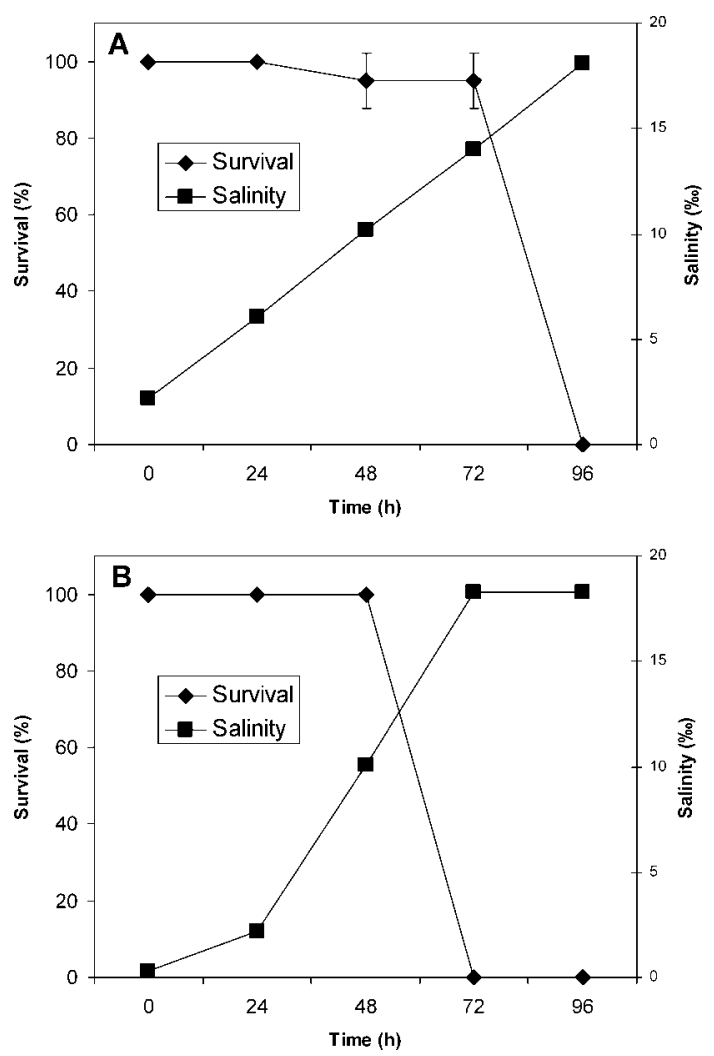

Figure 3.-Mean survival of juvenile flathead catfish exposed to synthetic seawater (Instant Ocean). Salinity was increased at a rate of (A) $4 \%$ /d or (B) $8 \%$ /d. Error bars indicate SDs. Points without error bars represent identical responses or negligible differences among replicates. 


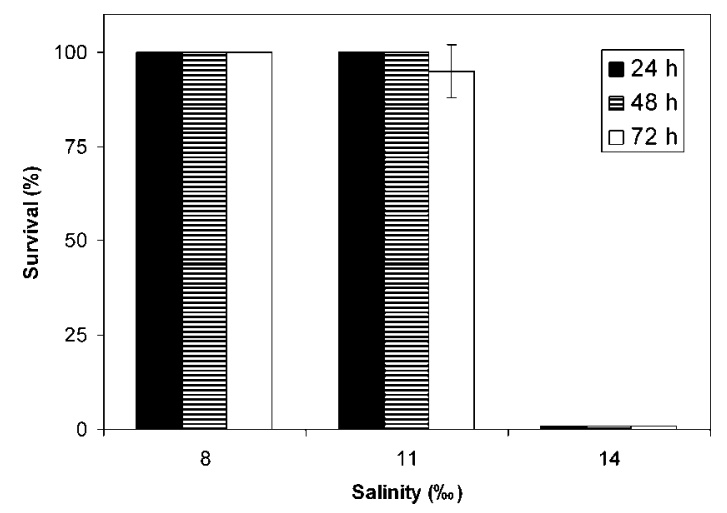

Figure 4.-Mean survival of juvenile flathead catfish exposed to synthetic seawater (Instant Ocean) for $24 \mathrm{~h}$, then transferred to freshwater for $48 \mathrm{~h}$ to assess latent mortality. Error bars indicate SDs. Points without error bars represent identical responses or negligible differences among replicates.

on published salinity tolerance data for other catfish species, our results suggest that use of synthetic seawater in salinity tolerance tests is more appropriate than $\mathrm{NaCl}$, because use of $\mathrm{NaCl}$ in salinity tolerance tests would probably result in an underprediction of the ability of flathead catfish to survive salinities of estuarine habitats. The reason for the greater tolerance of flathead catfish to synthetic seawater may be explained, in part, by the $\mathrm{NaCl}$ content of the synthetic seawater. Instant Ocean, like seawater, is $85 \% \mathrm{NaCl}$ by weight; therefore, the LC50 for synthetic seawater, when adjusted for $\mathrm{NaCl}$ content, is $12.3 \%$ o (95\% CI, $11.6-13.2 \%$ ), whereas the LC50 for $\mathrm{NaCl}$ was $10.0 \%$ (95\% CI, 9.0-11.1\%o). This finding suggests that sodium, chloride, or their combination may be the predominant contributor to toxicity in seawater. However, even with $\mathrm{NaCl}$ normalization, the LC50 for synthetic seawater is significantly greater than that for $\mathrm{NaCl}$, suggesting that one or more of the additional components of synthetic seawater (e.g., sulfate, magnesium, potassium, and calcium) may have mediated $\mathrm{NaCl}$-induced toxicity.

Fish in an estuarine environment would most likely be exposed to gradual changes in salinity, rather than abrupt changes, as modeled in direct transfer toxicity tests. Some fishes are able to acclimate to higher salinities with gradual increases in salinity than with direct transfer into brackish waters (Eddy 1981; Chervinski 1984; Anyanwu 1991). In our study, salinity tolerance of flathead catfish was greater $(15.8 \%$ ) when fish were acclimated at a rate of $4 \%$ od than in the direct transfer tests $(14.5 \%$ o). A more gradual rate of increase may result in even greater salinity tolerance.

The results of our research demonstrate that flathead catfish not only can tolerate direct transfer to brackish waters but also can survive the converse transition from brackish water to freshwater. These results suggest that dispersal of introduced flathead catfish populations may not be limited by the salinity of estuarine waters, although our tests were conducted at a constant temperature $\left(18^{\circ} \mathrm{C}\right)$ and should thus be interpreted with some caution. Nonetheless, the combined results of our laboratory tests are indicative of a scenario where flathead catfish may migrate from a freshwater river, through brackish coastal waters, and ascend another river system.

Additionally, several factors affect the salinity of estuaries, such as wind direction and speed, seasonal flow of rivers, and extreme flood events, such as hurricanes. For example, from 1993 to 2001, salinity concentrations in the Neuse River Estuary (North Carolina) ranged from 0 to $5 \%$ in

TABLE 3.-Comparison of laboratory-derived salinity tolerances (median lethal concentration [LC50]) of fishes in the family Ictaluridae.

\begin{tabular}{|c|c|c|c|}
\hline Species & LC50 $(\% \circ)$ & Reference & Notes \\
\hline Flathead catfish & $\begin{array}{l}10.0 \\
14.5 \\
15.8\end{array}$ & $\begin{array}{l}\text { Present study } \\
\text { Present study } \\
\text { Present study }\end{array}$ & $\begin{array}{l}\text { Direct transfer }(\mathrm{NaCl}) \\
\text { Direct transfer (synthetic seawater) } \\
\text { Acclimated (synthetic seawater) }\end{array}$ \\
\hline \multicolumn{4}{|l|}{ Channel catfish } \\
\hline Ictalurus punctatus & $\begin{array}{l}12.0 \\
15.5\end{array}$ & $\begin{array}{l}\text { Allen and Avault } 1969 \\
\text { Clemens and Jones } 1955\end{array}$ & $\begin{array}{l}\text { Diluted seawater } \\
\text { Brine pond water }\end{array}$ \\
\hline \multicolumn{4}{|l|}{ White catfish } \\
\hline Ameiurus catus & 14.0 & Kendall and Schwartz 1968 & Diluted seawater \\
\hline \multicolumn{4}{|l|}{ Black bullhead } \\
\hline Ameiurus melas & $\begin{array}{l}10.0 \\
13.8\end{array}$ & $\begin{array}{l}\text { Chipman } 1959 \\
\text { Clemens and Jones } 1955\end{array}$ & $\begin{array}{l}\text { Acclimated (brine pond water) } \\
\text { Brine pond water }\end{array}$ \\
\hline
\end{tabular}




\section{Chesapeake Bay Salinity Zones}

\section{Typical Spring}
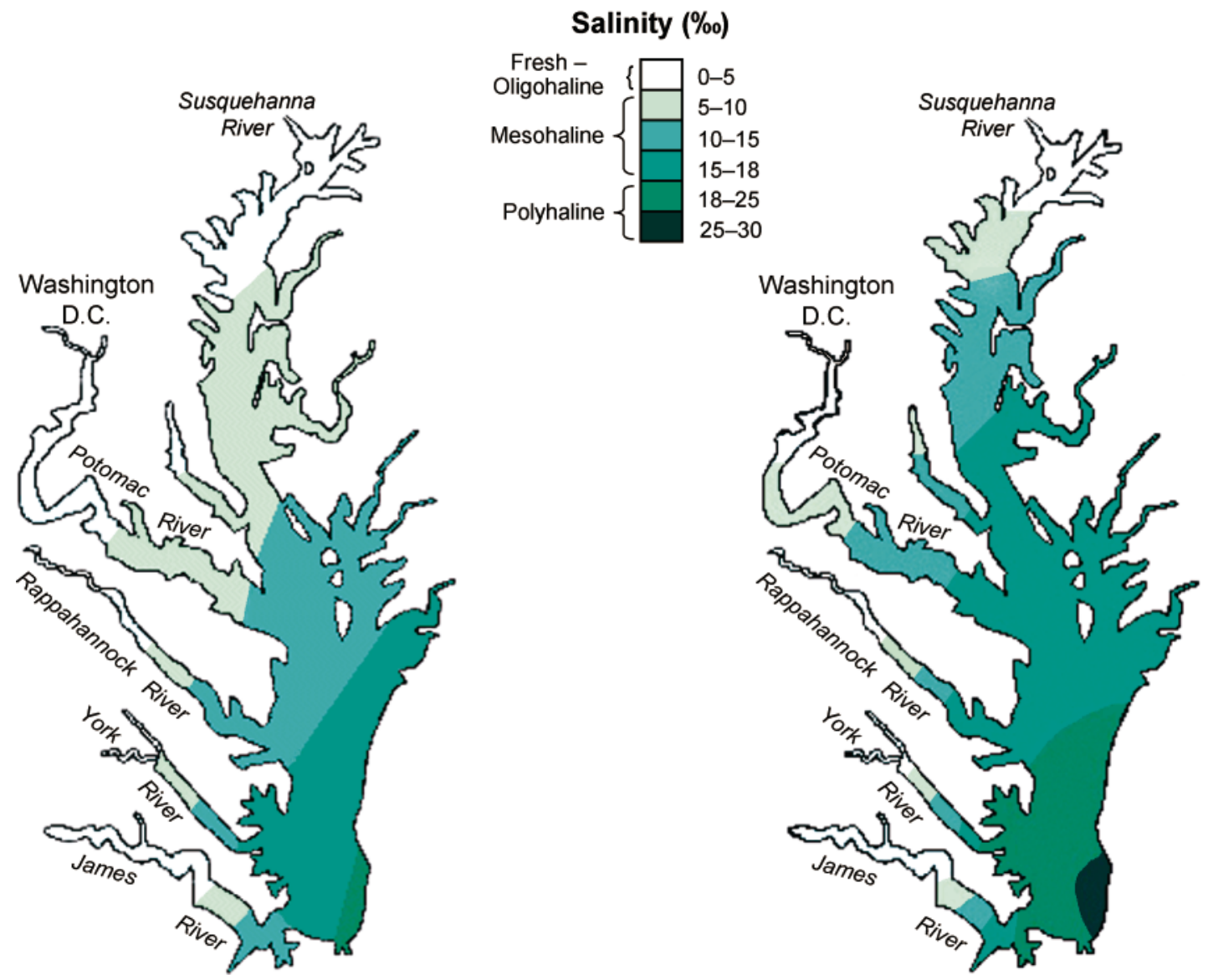

\section{Typical Fall}

FIgURE 5.- Map of the Chesapeake Bay showing the salinity zones typically encountered in spring and fall, which may influence the dispersal of introduced flathead catfish (modified from Maryland Department of Natural Resources).

spring to about $20 \%$ in late summer and followed a fairly consistent annual pattern (Reed et al. 2004). However, distinct differences in the salinity pattern were evident in years in which significant event-driven freshwater inputs occurred, including Hurricanes Fran (1996) and Floyd (1999) and another freshwater flooding event (1998). For about 2 months after Hurricane Floyd, salinity in the entire Neuse Estuary was freshwater to oligohaline (0.5-5\% ; Burkholder et al. 2004; Reed et al. 2004). Similar trends have been reported in the Albemarle-Pamlico Estuarine System in North Carolina and Virginia (Burkholder et al. 2004). High freshwater input events such as these would certainly broaden the spatial limits that salinity would impose on dispersal of introduced flathead catfish.

On a larger ecosystem scale, such as the Chesapeake Bay estuary, recurring seasonal salinity flux also is typical and may limit flathead catfish migration only seasonally (Figure 5). In a typical spring, a large proportion of the bay is tidal freshwater, oligohaline, or mesohaline water $(\leq 15 \%)$. Based on our results, during this time, introduced flathead catfish populations could potentially use much of the bay for movement between and among most of the rivers that flow into the estuary. Introduced flathead catfish populations currently ex- 
ist in the James and Potomac River systems of Virginia (Jenkins and Burkhead 1994). And although flathead catfish populations have not been documented in the York and Rappahannock drainages, between the James and Potomac rivers, they have recently been established in the Susquehanna and Delaware drainages at the north end of Chesapeake Bay (Brown et al. in press). Given typical spring salinity patterns in the bay (Figure 5), our results suggest that flathead catfish from the Potomac River would not be limited by salinity from migrating to the Rappahannock River or any river to the north, including the Susquehanna, Chesapeake, and Delaware (via the Chesapeake and Delaware Canal) systems, but that James River flathead catfish would be isolated to that system. In contrast, during autumn, much of the bay is typically approaching polyhaline salinities (15$30 \%$ ), which would greatly reduce the potential for utilization by flathead catfish. Our results applied to typical field conditions may suggest an alternative natural mechanism by which flathead catfish were introduced to the Susquehanna and Delaware systems, but it does not explain the lack of flathead catfish occurrence in the Rappahannock system if suitable habitat is available there.

If this dispersal mechanism occurs in the field, expansion of the flathead catfish into other coastal river systems may be expected, but this would require migratory behavior on the part of the fish. Several previous studies of flathead catfish behavior in its native range described a sedentary or semimobile fish (Funk 1955; Dames and Coon 1989; Skains and Jackson 1995). However, recent research in rivers on native flathead catfish in Missouri (Vokoun 2003) and introduced populations in North Carolina (Kwak et al. 2004) demonstrates that the fish can be highly mobile, with movements exceeding 45 river $\mathrm{km}$ within a month and home range estimates up to 69 river $\mathrm{km}$. These new findings of high mobility further suggest that flathead catfish migration among coastal drainages may occur.

Knowledge of salinity tolerance of any fish species is important, and the implications of our research are especially so for the flathead catfish, a large carnivorous, invasive species that is also valued as a sport and food fish in its native range. Although this fish is difficult to culture, our results suggest that technically it could be cultured in brackish waters. Its ability to occupy brackish waters compels consideration for sampling; electrofishing, the most common technique for sampling flathead catfish (Quinn 1990; Justus 1994; Stauffer and Koenen 1999), would not be effective in brackish waters. Similarly, researchers using radio telemetry to study flathead catfish behavior would be unable to detect the radio signal in brackish water (Winter 1996), and researchers have lost signals of radio-tagged flathead catfish near coastal river mouths during winter months (Kwak et al. 2004). Our finding that flathead catfish may use brackish waters suggests that marine fisheries agencies should be concerned with the potential impacts introduced flathead catfish could exert on native marine invertebrate and fish resources. These same findings identify the migratory limits that salinity may impose on flathead catfish migration within and among coastal rivers. Results such as these provide critical knowledge toward enhancing populations of this fish in its native range and toward understanding and limiting introduced populations for conservation of native fishes.

\section{Acknowledgments}

We thank Damian Shea and Mike Holliman for constructive reviews of an early version of this manuscript. Wendell Porter was instrumental in attaining flathead catfish egg masses for culture, and Steve Marple and other staff at the Peter W. Pfeiffer State Fish Hatchery provided assistance in rearing those fish. LeRoy Humphries and Peter Lazaro provided technical assistance during the experiments. We thank Anthony Burrows of the Maryland Department of Natural Resources for assistance with modifications to Figure 5. This research was funded in part by the North Carolina Wildlife Resources Commission through Federal Aid in Sport Fish Restoration funds (Project F68).

\section{References}

Allen, K. O., and J. W. Avault, Jr. 1971. Notes on the relative salinity tolerance of channel and blue catfish. Progressive Fish-Culturist 33:135-137.

APHA (American Public Health Association), American Water Works Association, and Water Environment Federation. 1995. Standard methods for the examination of water and wastewater, 19th edition. APHA, American Water Works Association, and Water Environment Federation, Washington, D.C.

ASTM (American Society for Testing and Materials). 1993. Standard guide for conducting acute toxicity tests with fishes, macroinvertebrates, and amphibians. ASTM, E 729-88a, Philadelphia.

Anyanwu, P. E. 1991. Influence of salinity on survival of fingerlings of the estuarine catfish Chrysichthys nigrodigitatus (Lacépède). Aquaculture 99:157165. 
Armitage, K. S., and L. J. Olund. 1962. Salt tolerance of the brook stickleback. American Midland Naturalist 68:274-277.

Arunachalam, S., and S. R. Reddy. 1979. Food intake, growth, food conversion, and body composition of catfish exposed to different salinities. Aquaculture 16:163-171.

Ashley, K. W., and B. Buff. 1988. Food habits of flathead catfish in the Cape Fear River, North Carolina. Proceedings of the Annual Conference Southeastern Association of Fish and Wildlife Agencies 41(1987):93-99.

Ashley, K. W., and R. T. Rachels. 2000. Changes in redbreast sunfish population characteristics in the Black and Lumber rivers, North Carolina. Proceedings of the Annual Conference Southeastern Association of Fish and Wildlife Agencies 52(1998): 29-38.

Brown, J. J., J. Perillo, T. J. Kwak, and R. J. Horwitz. Implications of the flathead catfish Pylodictis olivaris introduction into the Delaware and Susquehanna drainages. Northeastern Naturalist. In press.

Burkholder, J., D. Eggleston, H. Glasgow, C. Brownie, R. Reed, G. Janowitz, M. Posey, G. Melia, C. Kinder, R. Corbett, D. Toms, T. Alphin, N. Deamer, and J. Springer. 2004. Comparative impacts of two major hurricane seasons on the Neuse River and western Pamlico Sound ecosystems. Proceedings of the National Academy of Sciences 101:9291-9296.

Chen, J.-C., and W.-C. Chen. 2000. Salinity tolerance of Haliotis diversicolor supertexta at different salinity and temperature levels. Aquaculture 181:191203.

Chervinski, J. 1984. Salinity tolerance of young catfish Clarias lazera. Journal of Fish Biology 25:147-149.

Chipman, R. K., 1959. Studies of tolerance of certain freshwater fishes to brine water from oil wells. Ecology 40:299-302.

Clemens, H. P., and W. H. Jones. 1955. Toxicity of brine water from oil wells. Transactions of the American Fisheries Society 84:97-109.

Dames, H. R., and T. G. Coon. 1989. Movements of channel and flathead catfish between the Missouri River and a tributary, Perche Creek. Transactions of the American Fisheries Society 118:670-679.

Eddy, F. B. 1981. Effects of stress on osmotic and ionic regulation in fish. Pages 77-102 in A. D. Pickering, editor. Stress and fish. Academic Press, London.

Finney, D. J. 1978. Statistical method in biological assay, 3rd edition. Charles Griffin and Company, London.

Fuller, P. L., L. G. Nico, and J. D. Williams. 1999. Nonindigenous fishes introduced into inland waters of the United States. American Fisheries Society, Special Publication 27, Bethesda, Maryland.

Funk, J. L. 1955. Movement of stream fishes in Missouri. Transactions of the American Fisheries Society 85:39-57.

Guier, C. R., L. E. Nichols, and R. T. Rachels. 1984. Biological investigation of flathead catfish in the Cape Fear River. Proceedings of the Annual Con- ference Southeastern Association of Fish and Wildlife Agencies 35(1981):607-621.

Haney, D. C., and S. J. Walsh. 2003. Influence of salinity and temperature on the physiology of Lima melanonotata (Cyprinodontiformes: Poeciliidae): a search for abiotic factors limiting insular distribution in Hispaniola. Caribbean Journal of Science 39:327337.

Jackson, D. C. 1999. Flathead catfish: biology, fisheries, and management. Pages 23-35 in E. R. Irwin, W. A. Hubert, C. F. Rabeni, H. L. Schramm, Jr., and T. Coon, editors. Catfish 2000: proceedings of the international ictalurid symposium. American Fisheries Society, Symposium 24, Bethesda, Maryland.

Jenkins, R. E., and N. M. Burkhead. 1994. Freshwater fishes of Virginia. American Fisheries Society, Bethesda, Maryland.

Justus, B. 1996. Observations on electrofishing techniques for three catfish species in Mississippi. Proceedings of the Annual Conference Southeastern Association of Fish and Wildlife Agencies 48(1994):524-532.

Kefford, B. J., P. J. Papas, L. Metzeling, and D. Nugegoda. 2004. Do laboratory salinity tolerances of freshwater animals correspond with their field salinity? Environmental Pollution 129:355-362.

Kendall, A. W., Jr., and F. L. Schwartz. 1968. Lethal temperature and salinity tolerance for white catfish, Ictalurus catus, from the Patuxent River, Maryland. Chesapeake Science 9:103-108.

Kwak, T. J., W. E. Pine III, D. S. Waters, J. A. Rice, J. E. Hightower, and R. L. Noble. 2004. Population dynamics and ecology of introduced flathead catfish. Division of Inland Fisheries, North Carolina Wildlife Resources Commission, Federal Aid in Sport Fish Restoration, Project F-68, Study 1, Final Report, Raleigh.

Matern, S. A. 2001. Using temperature and salinity tolerances to predict the success of the shimofuri gobi, a recent invader into California. Transactions of the American Fisheries Society 130:592-599.

Myers, J. J., and C. C. Kohler. 2000. Acute responses to salinity for sunshine bass and palmetto bass. North American Journal of Aquaculture 62:195202.

Ostrand, K. G., and G. R. Wilde. 2001. Temperature, dissolved oxygen, and salinity tolerances of five stream fishes and their role in explaining fish assemblage patterns. Transactions of the American Fisheries Society 130:742-749.

Partridge, G. J., and G. I. Jenkins. 2002. The effect of salinity on growth and survival of juvenile black bream (Acanthopagrus butcheri). Aquaculture 210: 219-230.

Perry, W. G., Jr. 1968. Distribution and relative abundance of blue catfish, Ictalurus furcatus, and channel catfish, Ictalurus punctatus, with relation to salinity. Proceedings of the Southeastern Association of Game and Fish Commissioners 21(1967):436-444.

Perry, W. G., Jr. 1973. Notes on the spawning of blue and channel catfish in brackish water ponds. Progressive Fish-Culturist 35:164-166. 
Perry, W. G., Jr., and J. W. Avault, Jr. 1969. Preliminary experiments on the culture of blue, channel, and white catfish in brackish water ponds. Proceedings of the Southeastern Association of Game and Fish Commissioners 22(1968):397-406.

Pine, W. E., III. 2003. Population ecology of introduced flathead catfish. Doctoral dissertation. North Carolina State University, Raleigh.

Quinn, S. P. 1990. Effectiveness of an electrofishing system for collecting flathead catfish. Pages 123129 in I. G. Cox, editor. Developments in electric fishing. Fishing News Books, Oxford, UK

Reed, R. E., H. B. Glasgow, J. M. Burkholder, and C. Brownie. 2004. Seasonal physical-chemical structure and acoustic Doppler current profiler flow patterns over multiple years in a shallow, stratified estuary, with implications for lateral variability. Estuarine, Coastal, and Shelf Science 60:549-566.

Skains, J. A., and D. C. Jackson. 1995. Linear ranges of large flathead catfish in two Mississippi streams. Proceedings of the Annual Conference Southeastern Association of Fish and Wildlife Agencies 47(1993):539-546.

Stauffer, K. W., and B. D. Koenen. 1999. Comparison of methods for sampling flathead catfish in the Minnesota River. Pages 329-339 in E. R. Irwin, W. A. Hubert, C. F. Rabeni, H. L. Schramm, Jr., and T. Coon, editors. Catfish 2000: proceedings of the international ictalurid symposium. American Fisheries Society, Symposium 24, Bethesda, Maryland.

Stickney, R. R., and B. A. Simco. 1971. Salinity tolerance of catfish hybrids. Transactions of the American Fisheries Society 100:790-792.

Thomas, M. E. 1995. Monitoring the effects of introduced flathead catfish on sport fish populations in the Altamaha River, Georgia. Proceedings of the Annual Conference Southeastern Association of Fish and Wildlife Agencies 47(1993):531-538.

Vokoun, J. C. 2003. Movement and habitat use of flathead catfish (Pylodictis olivaris) in two Missouri interior streams. Doctoral dissertation. University of Missouri, Columbia.

WEST, Inc., and D. D. Gulley. 1994. TOXSTAT 3.4. Western EcoSystems Technology, Cheyenne, Wyoming.

Winter, J. 1996. Advances in underwater biotelemetry. Pages 555-590 in B. R. Murphy and D. W. Willis, editors. Fisheries techniques, 2nd edition. American Fisheries Society, Bethesda, Maryland. 